\title{
In what sense can a Christological image of the Divine provide cultural orientations?
}

\author{
Author: \\ Michael Welker \\ Affiliation: \\ ${ }^{1}$ Faculty of Theology, \\ University of Heidelberg \\ Germany \\ Correspondence to: \\ Michael Welker \\ Email: \\ mw@uni-hd.de \\ Postal address: \\ Faculty of Theology, \\ University of Heidelberg, \\ Kisselgasse 1, 69117 \\ Heidelberg, Germany

\section{Dates:} \\ Received: 13 Jan. 2011 \\ Accepted: 18 July 2012 \\ Published: 08 Nov. 2012 \\ How to cite this article: \\ Welker, M., 2012, 'In what \\ sense can a Christological \\ image of the Divine provide \\ cultural orientations?', In die \\ Skriflig/In Luce Verbi, 46(1), \\ Art \#54, 4 pages. http:// \\ dx.doi.org/10.4102/ids. \\ v46i1.54
}

A few years ago, some colleagues from the universities of Heidelberg, Chicago, Harvard and Yale tried to launch a research project which was meant to explore fruitful commonalities and differences amongst the Jewish, Christian and Islamic faith traditions. Over against conventional doctrinal and comparative religious explorations, it intended to explore the impacts which basic contents and forms of faith have on societies and cultures. This approach was also chosen to relate different traditions of research to each other - one more dominant in the European and the other in the Anglo-American world, namely that of the history of ideas (Geistesgeschichte) and the other based on cultural and social studies. As a title of these investigations, the majority of the group voted for Images of the Divine and cultural orientations. At that time, however, we did not discuss the standards and qualities we wanted to connect with the vision of cultural orientations. Nor did we deal with what one could call 'the iconic problem' in religious contexts.

Tot watter mate kan 'n Christologiese beeld van God kulturele oriënterings voorskryf? 'n Paar jaar gelede het verskeie kollegas van die universiteite van Heidelberg, Chicago, Harvard en Yale onderneem om 'n navorsingsprojek van stapel te stuur met die bedoeling om vrugbare of lonende ooreenkomste en verskille tussen die Joodse, Christelike en Islamitiese geloofstradisies te ondersoek. In teenstelling met konvensionele dogmatiese en vergelykende religieuse verkenningstogte, was die bedoeling hier om die impak wat basiese inhoude en vorme van geloof het op gemeenskappe en kulture vas te stel. Hierdie benadering is ook verkies om die verskillende navorsingstradisies met mekaar in verband te bring - die een is meer algemeen in die Europese en die ander in die Anglo-Amerikaanse wêreld, naamlik die geskiedenis van idees (Geistesgeschichte), en die ander gebaseer op kulturele en sosiale studies. As naam vir hierdie ondersoek het die meerderheid van die groep Images of the Divine and Cultural Orientations (Beelde van God en kulturele oriëntasies) verkies. Destyds het ons egter nie die standaarde en waardes bespreek wat ons met die idee van kulturele oriënterings wil verbind nie en ons het ook nie dit wat na verwys kan word as die 'ikoniese probleem' in religieuse kontekste, hanteer nie.

\section{The iconic problem and the vague vision of cultural orientations}

Jewish, Christian and Muslim traditions share in different forms and to different degrees the rejection of what is called image-worship:

You shall not make for yourself a graven image, or any likeness of anything that is in heaven above, or that is in the earth beneath, or that is in the water under the earth; you shall not bow down to them or serve them ... (Ex 20:4ff.; cf. Dt 4:16-19; 5:8)

But then we find a multitude of mental images of the Divine and of divine glory in the holy scriptures. In the Tanach, human beings are called the 'image of God' (Gn 1:26ff.; 5:1; 9:6), and in the New Testament they receive the promise that they will bear the image of the second anthropos from heaven (1 Cor 15:49; cf. Rom 8:29), namely the risen Jesus Christ 'who reflects the glory of God and bears the very stamp of His nature' (Heb 1:3). How can we relate aniconism and these claims about God's revelation?

The iconic problem is not only a theological puzzle. It can also be raised with respect to any call for cultural orientations. Is a powerful image or icon or even a regulative illuminating idea already a candidate for cultural orientation? Kathryn Tanner (1997; cf. Welker 2009), Terry Eagleton (2000) and others have alerted us to the enormous complexity of the phenomenon of culture, which might explain the fascination and enthusiasm in the academy and in the media today for this topic. Culture comes with a realistic and a constructivist dimension. It can be a descriptive, an evaluative and even a normative term. It includes the actual and a desirable notion of reality and - 
at least in a cloudy way - a vision or visions of perfection. It is not only seen as a complex human activity, but as a complex state of actual and possible human affairs; it concentrates not only on natural reality, but also on spiritual and symbolic reality. In the 18th century, culture became equated with civilisation and correlated with all kinds of modern progress. It was associated with tradition and with resistance, with the elite and with the mass.

Since Herder at the latest, we see the pluralisation of culture as a standard of thought about it, the critique of its Eurocentrism, and the emergence of a multicontextual way of analysing it. The nuanced approach towards the different cultures across the globe and a continuous growth in the awareness of the social and cultural differentiations in complex societies became the standard for all relevant investigations of the topic. Terry Eagleton (2000) noticed laconically:

The complexity of the idea of culture is nowhere more graphically demonstrated than in the fact that its most eminent theorist in post-war Britain, Raymond Williams, defines it at various times to mean the standard of perfection, a habit of mind, the arts, general intellectual development, a whole way of life, a signifying system, a structure of feeling, the interrelations of elements in a way of life and everything from economic production and the family to political institutions. (p. 36)

Most of the definitions and theories of culture, however, seem to agree explicitly or implicitly that cultures serve to secure continuities in the communication of human beings via memories and expectations. With the help of their culture(s), human beings develop amazing abilities to connect and to disconnect, to share and to differentiate, their memories and their expectations. In our memories and imaginations we anticipate, reproduce and reconstruct what others remember, anticipate and expect. Moving in the realms of memory and imagination, we attune individual and communal emotions, thoughts and practices in very powerful ways. The enormous individual and communal power to create worlds of memories and imaginations, to store, select, connect and shape them and to process and attune powerful streams of information, illumination and attuned thoughts, emotions, habits and practices is not only attributed to culture, but also to the human spirit. And the complex relation between the human spirit and the Divine Spirit opens routes to explore what we envisioned under the title Images of the Divine and cultural orientations.

The challenge to understand the processes of communal, cultural, collective and canonic memory and of communal, cultural, collective and canonic imaginations and their impact on the different societal systems and associations under the condition of different traditions, of educational, familial, religious, legal, political and other institutions and organisations is enormous (Assmann 1992; Welker 2008:321-331). It is even heightened by the awareness that the flux of our cultural orientations has to wrestle with enormous local and global distortions, such as, (1) the massive injustice, poverty and ecological destruction in the contemporary world, (2) the threat of relativism, cynicism and apathy, (3) the weakening and corruption of cultural and canonic memory by the enormous powers of the market, the media and technology, (4) the long-term crisis and the potential restitutions of the ideologies of the nation-state in the context of the current crisis of the monetary system and (5) the different speed of shifts from modern to postmodern paradigms and mentalities across the globe, to name just a few obvious challenges (Welker 2002b)

In our project, it would probably be wise to develop diagnostic proposals of the complex sphere of cultural orientations, by focusing on the symbolic, liturgical, cognitive and normative religious powers which we see at work in the different faith traditions. In this respect, however, I should like to question whether the focus on images of the Divine can really prove to be helpful. To be sure, we can investigate the symbolic power of different images, icons and metaphors which inspire and illuminate our religious thinking and our practices. But I wonder whether a move from the iconic turn to a spiritual turn might not be more helpful and even necessary. Instead of images of the Divine and cultural orientations, I propose to think about and speak of the spiritual presence of the Divine and cultural orientations, for reasons I will discuss in the sections to follow.

\section{Religious, ethical and prophetic dimensions of the Divine presence}

The anthropological investigation of the imago Dei, the image of God, in our faith traditions can be regarded as a common ground of discourse - at least between the Christian and the Jewish traditions. In the Christian theological perspective, it is unavoidable to finally shift from the general anthropological notion of the imago Dei to the Christological notion and to reflect anthropological patterns and affairs in a Christological light. However, if we merely concentrate on the iconic presence of Jesus Christ in its anthropological shape, we will easily get stuck with the very powerful icons of the cradle and the cross, the beginning and the end of Jesus' life, with the message of the incarnation and the kenosis and the insistence on a specific nearness of God in this life and person. Such an approach will not only easily divide our faith traditions, it will also block the perspectives on the cultureshaping powers of the resurrected and elevated Christ. In contrast to this bottom-up anthropological approach, it is noteworthy that Paul, in his soteriological and eschatological perspectives, does not envision a transformation of the believers into the image of the pre-Easterly human nature of Christ. He rather speaks of a transformation into the image of the 'Lord who is the Spirit' (2 Cor 3:18). What does this mean for our search for cultural orientations?

The standard message of many recent theologies of the cross used to be that the focus on the condescending and suffering God challenges the self-aggrandisation of human beings, their attempts to dominate the world and other people, and to behave in a god-like manner. In my view, this message 
has hardly served a subtle cultural analysis and realistic cultural orientations. In this form, it was not much more than a complex moral appeal to human modesty and humility. We gain a very different approach when we consider the differentiated spiritual presence of the Divine, which, from the Christian perspective, has a Christo-morphic shape in its orientation towards the incarnation, the cross and the resurrection of Christ. This differentiated perspective has to be unfolded pneumatologically. In the power of the Spirit, the resurrected and elevated Christ is not without his witnesses; the elevated and spiritual personhood comes indeed in the dimension of a differentiated reign. Tertullian saw this when he stated, Jesus Christ is the reign of God in person. I see a threefold spiritual presence in this light, which will strongly interconnect with, and relate to, other faith traditions.

The first spiritual presence which Christian faith can begin to associate with the reign of God in the light of the preEaster life of Christ generates a theological humanism (Klemm \& Schweiker 2008; Schweiker 2009:85-102; Vorster 2010). This humanism is supported in the orientation towards the caring and sustaining and rescuing God whom Christians see revealed in the brotherly lordship and the 'kingly office of Christ', which establishes an ethos of freedom grounded in love and responsibility (Schweiker 2009:85-102). It starts with the care for the very basic human needs, such as nourishment, healing and fellowship. The reductionistic, but nevertheless important, insights of the so-called 'third quest for the historical Jesus' research emphasise these aspects. It stands in continuity and is deeply gounded in the biblical law-traditions with their care for justice, mercy and the search for truth 'before God' (Welker 1986, 2002a). The strict correlation of justice and mercy challenges the legal evolution to move into humane directions; the correlation of mercy and justice urges the morals of compassion to strive for diaconical social institutions. The ethos of love and forgiveness aims at transposing the powers of intimate family-relations into broader social constellations. These cultural radiations are intensely correlated with the familial and educational systems, with the establishment of a broad network of institutions of human aid and social care. It aims at shaping human cultures with an ethos of equality and freedom, and it presses for the establishment and execution of human rights.

The second dimension brings the revealing and judging aspects of the presence of the Divine, which Christians attribute to the prophetic office of Christ, and which should be correlated with the complex understanding of the dimension of the cross. The cross does not only reveal the co-suffering and kenotic presence of God, it also discloses the principalities and powers which work against the presence of God and the powers of love. The cross reveals the corruption of religion, politics, law, morals and public opinion. The prophetic office of the Spirit engages the real and symbolpolitical conflicts in human societies and cultures, the critique and self-critique of religion, the critique of political and moral and legal developments which are not compatible with the search for justice, mercy and truth, and the love of freedom and peace. The prophetic office of the Spirit is not only a religious and moral alarm-system. It leads to the development of politics of memory, which keep the atrocities of the human history of violence, oppression, genocide, the bloody traces of imperialism and colonialism in the public mind and in general education. But it also opens perspectives of realistic hope and teaches the constant 'discernment of the spirits' and the wrestling with the powers of sin (Smit 2009:19-49).

Finally, we have to refer to the sanctifying and ennobling presence of the divine, which, again in a Christian perspective, is correlated with the 'priestly office of Christ' and with the powers revealed in the resurrection. As Francis Fiorenza (1997:213-248; cf. Peters, Russel \& Welker 2002) has shown, the resurrection reveals very basic spiritual forms of the constitution of the life of the church, such as the breaking of the bread, the illumination and opening of the Scriptures, the greeting of peace, the sending of the disciples, et cetera basic forms which Christians connect with the constitution of the body of Christ and its service in the world. The priestly office should by no means become restricted to sacrifice and atonement only. Although the priestly dimension of the spiritual presence sustains the liturgical identity of the specific faith tradition, it is strongly interrelated with the diaconical and the prophetic dimensions which do not only reach out far beyond the realms of the Christian churches, but which often work against their strategies of self-sustenance and self-protection.

All three dimensions of the spiritual presence of the Divine, which Christians see revealed in the life and lordship of Jesus Christ, show various interdependences and a multitude of specific radiations into the different spheres of our cultures, our systems of memories and imaginations. They show different modes of support and of critical challenge of the secular cultural shaping powers which we should investigate in a realistic comparative discourse, with topical foci which promise mutual challenge and illumination amongst our traditions of faith.

At first glance, starting with a reflection on 'Christ as the imago Dei' might look like Christocentric triumphalism. However, this is relativised when we consider the threefold pattern of a reign of God, of which the cultivation of spiritual, liturgical, educational forms and markers of the identity of a specific faith tradition is only one dimension (Fishbane 2008). The spiritual realm we have described develops modes of thought, of moral and religious orientation which are to be developed not only within a specific faith community, but in a much broader context of societies and cultures and which can also challenge convictions and attitudes of the individual faith tradition.

\section{Conclusion}

The ethos of the search for justice, compassion and truth is deeply rooted in Jewish, Christian and Islamic contexts. It has spread into the moral, legal, political and educational 
institutions, organisations and civil societal contexts across the globe. What Christians identify with the reign of Christ and the Spirit of love and forgiveness is named differently in other traditions of faith. We will, however, not only see different names but also different modes of thought and practices in the horizons of similar intentions. This will provide many resources of cultural orientation in the form of discourse, dialogue, fruitful difference and mutual challenge. The academic, religious and cultural stress in terms of difference and mutual challenge will be most pressing in the realm which I marked by the name of the prophetic office of the Spirit. In the diverse religious, societal, national and ethnic contexts, we will encounter different, even conflicting identifications of distortive developments and powers. There will be both agreement and dispute about the religious, moral, legal and educational means which will generate fruitful, humane and peaceful developments. The unfolding and translation of a Christological Image of the Divine into spiritual and reign-of-God images and patterns might provide potentials for interfaith communication, cooperation and mutually stimulated cultural creativity.

\section{Acknowledgements Competing interests}

The author declares that he has no financial or personal relationships which may have inappropriately influenced him in writing this article.

\section{References}

Assmann, J., 1992, Das kulturelle Gedächtnis, Schrift, Erinnerung und politische Identität in frühen Hochkulturen Beck, Munich.

Eagleton, T., 2000, The idea of culture, Blackwell, Oxford.

Fiorenza, F., 1997, 'The resurrection of Jesus and Roman Catholic fundamental theology', in S.T. Davis, D. Kendall \& G. O'Collins (eds.), The resurrection: An interdisciplinary symposium on the resurrection of Jesus, pp. 213-248, Oxford University Press, Oxford.

Fishbane, M., 2008, Sacred attunement: A Jewish theology, parts 2 and 3, The University of Chicago Press, Chicago.

Klemm, D.R. \& Schweiker, W., 2008, Religion and the human future: An essay on theological humanism, Blackwell, Oxford.

Peters, T., Russel, R. \& Welker, M. (eds.), 2002, Resurrection: Theological and scientific assessments, Eerdmanns, Grand Rapids.

Schweiker, W., 2009, 'Flesh and folly: The Christ of Christian humanism', in A. Schuele $\& \mathrm{G}$. Thomas (eds.), Who is Jesus Christ for us today? Pathways to contemporary Christology, pp. 85-102, Westminster John Knox, Louisville.

Smit, D., 2009, “Under Pontius Pilate": On living cultural memory and Christian confession', in A. Schuele \& G. Thomas (eds.), Who is Jesus Christ for us today? Pathways to contemporary Christology, pp. 19-49, Westminster John Knox, Louisville.

Tanner, K., 1997, Theories of culture: A new agenda for theology, Fortress, Minneapolis.

Vorster, J.,M., 2010, 'Der Beitrag der deontologischen christlichen Ethik zum heutigen Menschenrechtsdiskurs' [The contribution of Christian deontological ethics for today's human rights discourse], Evangelische Theologie 70, 246-262.

Welker, M., 1986, 'Security of expectations: Reformulating the theology of law and gospel', Journal of Religion 66, 237-260.

Welker, M. 2002a, 'Moral, Recht und Ethos in evangelisch-theologischer Sicht', in W. Härle \& R. Preul (eds.), Marburger Jahrbuch Theologie XIII, pp. 67-81, Elwert, Marburg.

Welker, M., 2002b, 'Modernity and post-modernity as challenges to Christian theology', Svensk Missions Tidskrift 90(4), 435-447.

Welker, M., 2003, 'Modernity', in Encyclopedia of Science and Religion, pp. 579-582, Macmillan, New York.

Welker, M., 2008, 'Kommunikatives, kollektives, kulturelles und kanonisches Gedächtnis', in Jahrbuch für Biblische Theologie, vol. 22, Die Macht der Erinnerung, pp. 321-331, Neukirchener Verlag, Neukirchen.

Welker, M., 2009, 'Theologie der Kultur' [Theology of Culture], Verkündigung und Forschung 54, 25-31. 